\title{
Medicinal effects of Propolis diet on biochemicals and histological factors in rats
}

\author{
Mahdi Bayrami ${ }^{1 *}$, Mansoor khakpoor ${ }^{2}$, Esmail Safavi ${ }^{3}$ and Abolfazl Bayrami ${ }^{4}$ \\ ${ }^{1}$ Faculty of Veterinary Medicine, Tabriz Branch, Islamic Azad University, Tabriz, Iran \\ ${ }^{2}$ Department of Pathobiology, Tabriz Branch, Islamic Azad University, Tabriz, Iran \\ ${ }^{3}$ Department of Basic Science, Tabriz Branch, Islamic Azad University, Tabriz, Iran \\ ${ }^{4}$ Department of Biology, Faculty of Sciences, Universiry of Mohagheghe Ardabili, Ardabil, Iran
}

\begin{abstract}
Background/aim: There is increasing interest in the healing potential of natural products, such as Propolis, considering the availability and low cost of these products. The present study was conducted to evaluate biochemical and histological effects of ethanol extract of Propolis (EEP) on intestinal tissue in rats.

Materials and methods: Healthy Wistar rats were indiscriminately assigned into three groups (A-C) and five rats in each. The group A were orally given 0.2 mL of dimethyl sulfoxide daily as a control, while rats in Groups B and C were administered the same $0.2 \mathrm{~mL}$ dimethyl sulfoxide containing 300 and $600 \mathrm{mg} / \mathrm{kg}$ body weight ethanol extract of bee Propolis for 21 days respectively.
\end{abstract}

Results: It has been concluded that ethanol extract of Propolis significantly increases globulin levels in group $300 \mathrm{mg} / \mathrm{kg}(p<0.05)$. It also, significantly increases the height of the villi, the thickness of the mucous membrane and muscles in the group $600 \mathrm{mg} / \mathrm{kg}(p<0.05)$.

Conclusion: It could be concluded from the present investigation that the Propolis has positive effect on animal hygiene by increasing the immunity and decreasing the stress via increase the globulin level in the blood, but the beneficial effect of Propolis seems to be dose dependent.

\section{Introduction}

The growing market for natural products and alternative medicines has renewed interest in bee products, such as honey, royal jelly, pollen, and propolis [1,2]. Propolis is a sticky honeybee resinous product with a wide array of biological application. This matter composes of flavonoids, resin, poly-phenol, phenolic acid, phenolic aldehyde, wax, terpenoids, steroids, amino acids and pollen [3,4]. The total concentration of phenol, and flavonoid compounds were $19.44 \%$ and $18.792 \%$ in the DEEP, respectively [5]. It was proposed that biological effects of propolis couldn't be attributed solely to these components, since the chemical composition of propolis is complex [6]. Propolis samples from Europe, South America, and Asia have different compositions and therefore have different biological activities [7-9]. Propolis is widely used to prevent and treat colds, wounds and ulcers, rheumatism, sprains, heart disease, diabetes $[10,11]$ and dental caries [12] due to its diverse biological properties such as anti-inflammatory $[11,13,14]$ antimicrobial, antioxidant, antitumor [15], antiulcer and anti-HIV activities [16]. Part of the antimicrobial activity is due to polar phenolic compounds specifically of the flavonoid fractions $[17,18]$. Bee propolis ingredient seems to stop cancer cell growth 13 and control the growth of human tumors $[19,20]$. propolis uses in sealing holes and cracks and for the reconstruction of the beehive. It is also used for smoothing the inner surface of the beehive, retaining the hive's internal temperature $\left(35^{\circ} \mathrm{C}\right)$, preventing weathering and invasion by predators. Furthermore, propolis hardens the cell wall and contributes to an aseptic internal environment. Propolis generally becomes soft and sticky upon heating [21]. In most developed countries, it used commonly in the different industries such as pharmacy, health food industry and livestock products especially in poultry. It has been traditionally used by Egyptians, Greeks, Romans, and Chinese to heal wounds and diseases of the gut, including gastric ulcers. It has also been used as a remedy for cough, sore throat, and earaches [22]. It can be used in various forms such as tablets, capsules, face creams, lip stick, ointment etc. [23].

Innate immunity forms the first line of immune defense and includes cellular and biochemical mechanisms [24]. Innate immunity ingredients include physical and chemical barriers like epithelium and anti-bacterial compounds derived from the epithelial layers, Blood proteins components of the complement system and other inflammatory mediators, etc. [25].

The intestinal is an important part of that has two critical functions:

a) With selective permeability it allows absorption of needed nutrients from the intestinal lumen into the circulation and internal milieu.

b) As a barrier, it prevents the penetration of harmful matters including microorganisms, luminal antigens, and luminal pro-inflammatory factors.

${ }^{\star}$ Correspondence to: Mahdi Bayrami, Faculty of Veterinary Medicine, Tabriz Branch, Islamic Azad University, Tabriz, Iran, E-mail: Mahdi.Bayrami@uma.ac.ir

Key words: Propolis, biochemicals, histological, immunity, intestinal

Received: November 21, 2019; Accepted: December 03, 2019; Published: December 09, 2019 
Barrier defenses include both immunogenic mechanisms such as immunoglobulin's and mucosal lymphocytes, and non-immunogenic mechanisms such as selective intestinal permeability. Intestinal permeability is a highly regulated dynamic process. The magnitude of permeation of molecules can serve as a quantitative means of assessing mucosal barrier integrity in health and disease. Several factors participate in regulation of intestinal permeability [26].

The aim of this study was evaluating the Effects of ethanol extract of Propolis (EEP) diet on biochemicals \& histological factors on intestinal tissue in rats.

\section{Material and methods}

\section{Preparation of propolis extract (EEP)}

Two hundred grams of propolis pellets were percolated in 1600 $\mathrm{mL}$ of pure ethanol (97\%) and subsequently allowed to stand in the shade for $48 \mathrm{~h}$ before filtration, using filter paper (Whatman No. 1). The extract concentrate was stored in air-tight vials in the refrigerator at 4 ${ }^{\circ} \mathrm{C}$, until needed for bio-assay.

\section{Experimental animals}

Fifteen female wistar Albino rats (average weight 180-200 g) were used in the present experiment. The experiment was performed in accordance with internationally accepted guidelines for the use of animals. Animals were housed in steel cages and maintained under standard conditions ( $12 \mathrm{~h} \mathrm{light} / 12 \mathrm{~h}$ dark cycle; $25 \pm 3^{\circ} \mathrm{C} ; 35-60 \%$ relative humidity), and received standard pelleted diet and unlimited water during the study period. Fifteen Wistar rats were divided into three groups of 5 rats each. The control rats (Group A) were given 0.2 $\mathrm{mL}$ of dimethyl sulfoxide. The extract treated rats (Groups B and C) were given equal volume of dimethyl sulfoxide containing 300 and 600 $\mathrm{mg} / \mathrm{kg}$ body weight of ethanol extracts of propolis (EEP) once a day for 21 days respectively [27].

\section{Collection of blood and serum preparation}

The animals were anaesthetized in ether vapor. Blood samples were collected from tail. The veins were sharply cut with sterile blade and the bloods were collected into clean tubes containing no anticoagulant. The clotted blood samples at room temperature were centrifuged for 15 $\mathrm{min}$ at $33.5 \mathrm{r} / \mathrm{min}$ and the cleared serum was pipette into a clean well labeled serum bottle.

\section{Histopathological section preparation}

Tissues taken from intestinal (Duodenum) of rats were cut and immediately fixed into $10 \%$ formaldehyde saline. Tissues were processed for preparation of paraffin blocks (paraffin method). Sections were cut by rotatory microtome and mounted on glass slides. The sections were stained by conventional Hematoxylin and Eosin (H\&E) stain. The sections were observed by light microscope.

\section{Biochemical and hematological exams}

The white blood cell from complete blood was counted by Neobar method. The level of serum total proteins and serum albumin were estimated using biuret and BCG respectively. Ultimately, gamma globulin levels were measured by electrophoresis. Blood proteins divide into two general categories of albumin and globulin. Serum globulin concentration was determined according to the formula:

Globulin=total protein-albumin

\section{Statistical analysis}

Data was expressed as mean values $\pm S D(n=5)$. Statistical analysis was performed using one-way analysis of variance (ANOVA) to assess significant difference among treatment groups then the post hoc Tukey's test was used for comparisons at $\mathrm{P}<0.05$. Data was analyzed using SPSS statistical version 16 software package.

\section{Results}

\section{The results of biochemical experiments and WBC}

Figures 1 and 2 illustrate the changes in the WBC, total protein, albumin, globulin and gamma globulin following 21 days administration of ethanol extract of propolis. The 21 days administration of the extract resulted no significant changes in serum total protein, albumin, gamma globulin and $\mathrm{WBC}$ of the rats $(\mathrm{P}>0.05)$. However, there was a significant increase in globulin on the group $300 \mathrm{mg} / \mathrm{kg}$ in comparison with control $(\mathrm{P}<0.05)$.

\section{Histomorphometric results}

The effects of 21 days daily administration of ethanol extract of propolis on intestinal tissue in rats are shown in the Table 1 . The villi height and thickness of mucous layer in rats given $600 \mathrm{mg} / \mathrm{kg}$ of propolis extract, increased significantly $(\mathrm{P}<0.05)$ in comparison with $300 \mathrm{mg} / \mathrm{kg}$ and control groups. Also muscular thickness in rats given $600 \mathrm{mg} / \mathrm{kg}$ of propolis extract increased significantly $(\mathrm{P}<0.05)$ compared to control

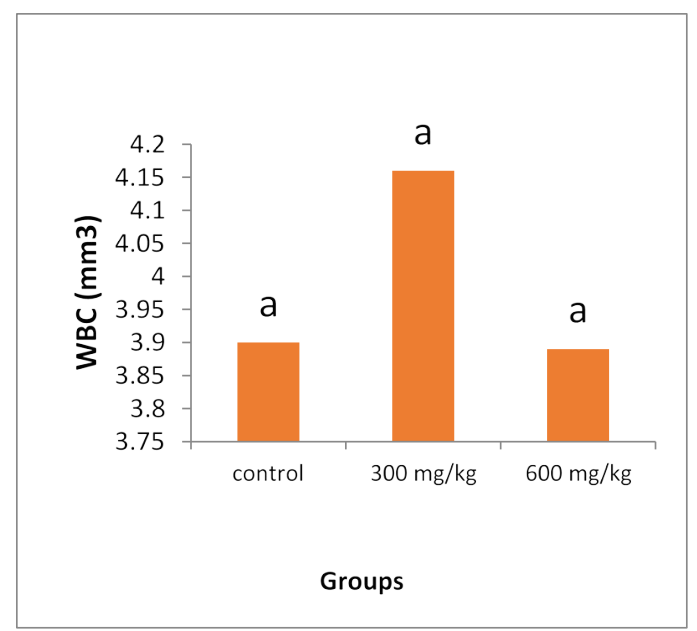

Figure 1. Changes in WBC level. Each column represents the mean $\pm S D, n=5$

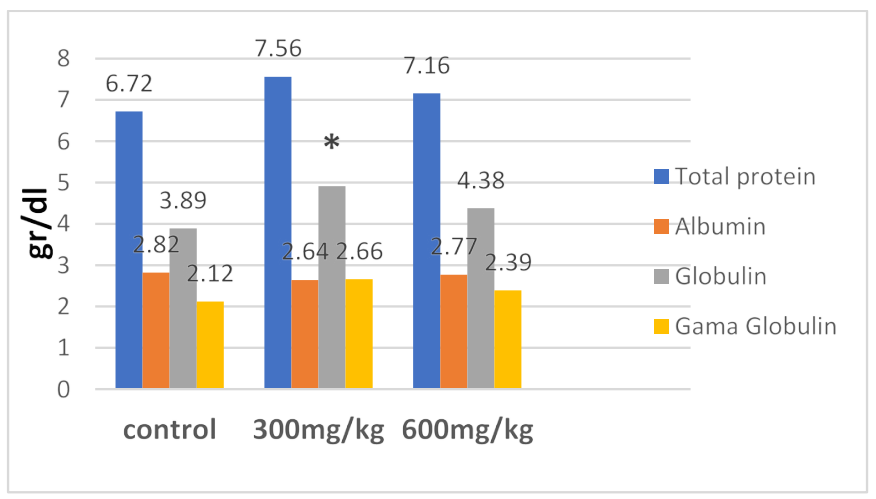

Figure 2. Effect of ethanol extract of propolis (EEP) on biochemicals "The significance different with control $(p \leq 0 / 05)$ 
group, however there was no histomorphometric difference in $300 \mathrm{mg} /$ $\mathrm{kg}$ extract compared to the control group (Figures 3 and 4).

\section{Discussion}

Evaluation of biochemical indices in serum and organs of animals has become the most valuable tools for assessing the integrity and functionality of organs as well as risk assessment, pathological condition and general health status of the body. Defeat in the activities of these biomarkers in serum and body tissues are to a sensible degree the detrimental effect of a drug or extract/compound under investigation [28]. The large number of chemical components in propolis may justify its many biological activities. However, it is possible to hypothesize that its complex composition may lead to damage in the organism [29]. Lauwerys et al. in 1995 reported the importance of choosing the biological components to be determined in dose-effect relation studies, mainly when the drug action mechanism, as in propolis, is not clear. Thus, alterations in these variables help in the understanding of biological effects related to treatment [30].

In this work, biochemical and histological determinations in rats treated with 300 and $600 \mathrm{mg} / \mathrm{kg}$ of propolis extract were performed 21 days after propolis diet.

Our results showed that all dosages induced no significant alterations in levels of total protein, albumin, gama globulin and WBC, when compared to the control group. Effect of a material on synthetic action liver show with Albumin level. Since, there is a toxically substance in body; serum Albumin level will decrease, because liver found toxically case [31]. As monitored in Figure 2, there is no significant difference between different levels of alcoholic extract propolis in albumin level ( $p>0.05$ ) but it is lower in $300 \mathrm{mg} / \mathrm{kg}$ diet group than others. Our findings in this research are consistent with the results reported in a study on broiler [31].

Concerning the globulins, $300 \mathrm{mg}$ alcoholic extract propolis per $\mathrm{kg}$ diet group in between experimental groups was higher levels. Increase of globulin concentration may be attributed to stimulation of immune system by propolis flavonoid [32]. This finding agreed with the results of $[33,34]$, who reported that the globulin was significantly $(\mathrm{p}<0.01)$ increase in propolis treated ewes. However [35], found that propolis have no significant effect on serum total protein, albumin and globulin. Many reports indicating that propolis has immunostmulant effect and maintaining good health. As reported previously, using propolis increases the weight of the thymus, Lymph nodes, fabricius (BF), as well as levels of blood antibodies [36]. In another study [37] showed that propolis stimulates cellular and humoral immune system. While the antioxidants effect on improving the immune system is remarkable so propolis can decreases signs of mellitus diabetes in mice due to its antioxidant property [4]. Besides that, propolis enhances the useful intestinal micro flora which is important indicator of innate immunity. As demonstrated using ethanol extract of propolis in broiler chicken diets, not only suppress aerobic and coliform bacterial but also increase both lactobacilli and bifidobacteria in the intestinal Besides that effect, food conversion rate, growth performance and finally immune

Table 1. Effect of ethanol extract of propolis (EEP) on the intestinal parameters in rats

\begin{tabular}{|c|c|c|c|c|c|c|}
\hline \multicolumn{7}{|c|}{ Factors } \\
\hline & $\begin{array}{l}\text { Villi height } \\
\qquad(\mu \mathrm{m})\end{array}$ & $\begin{array}{l}\text { Crypt depth } \\
(\mu \mathrm{m})\end{array}$ & $\begin{array}{l}\text { Epithelium thickness } \\
\qquad(\mu \mathrm{m})\end{array}$ & $\begin{array}{c}\text { Mucousal } \\
\text { layer thickness } \\
(\mu \mathrm{m})\end{array}$ & $\begin{array}{c}\text { Muscular thickness } \\
(\mu \mathrm{m})\end{array}$ & $\begin{array}{l}\text { Goblet cell } \\
\text { (No/villi) }\end{array}$ \\
\hline $\begin{array}{l}\text { Groups } \\
\text { Control }\end{array}$ & $6.24 \pm 12.78^{\mathrm{a}}$ & $2.47 \pm 12.04^{\mathrm{a}}$ & $27.03 \pm 1.21^{\mathrm{a}}$ & $8.97 \pm 12.16^{\mathrm{a}}$ & $92.56 \pm 2.79^{\mathrm{a}}$ & $9 \pm 0.36^{a}$ \\
\hline $300 \mathrm{mg} / \mathrm{kg}$ & $6.03 \pm 20.54^{\mathrm{a}}$ & $2.63 \pm 16.29^{\mathrm{a}}$ & $24.73 \pm 1.26^{\mathrm{a}}$ & $8.88 \pm 19.08^{\mathrm{a}}$ & $1 \pm 4.16^{\mathrm{ab}}$ & $9.4 \pm 0.52^{\mathrm{a}}$ \\
\hline $600 \mathrm{mg} / \mathrm{kg}$ & $7.15 \pm 17.78^{b}$ & $2.53 \pm 13.48^{\mathrm{a}}$ & $27.79 \pm 1.28^{\mathrm{a}}$ & $9.83 \pm 15.4^{b}$ & $1.09 \pm 4.25^{\mathrm{b}}$ & $9.5 \pm 0.63^{\mathrm{a}}$ \\
\hline
\end{tabular}

Values represent the mean $\pm \mathrm{SD}, \mathrm{n}=5$.

Different letters in each column indicate significant difference between groups $(p<0.05)$.
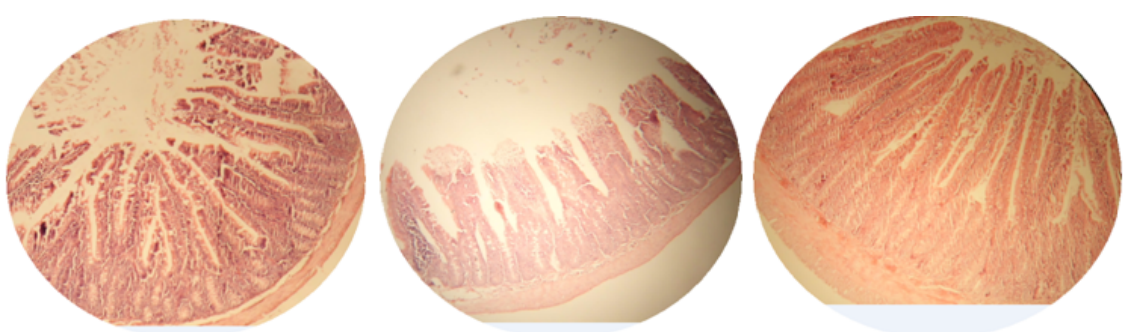

Figure 3. Photomicrographs of intestine using H\&E stain (40X). Small intestine of rats showing its characteristic layers; mucosa, submucosa, musculosa and serosa. A) Control group is showing normal architecture in the villis. B) $300 \mathrm{mg} / \mathrm{kg}$ group is showing no significant changes. C) $600 \mathrm{mg} / \mathrm{kg}$ group is showing increase of the villis height, the thickness of mucous membrane and muscle thickness
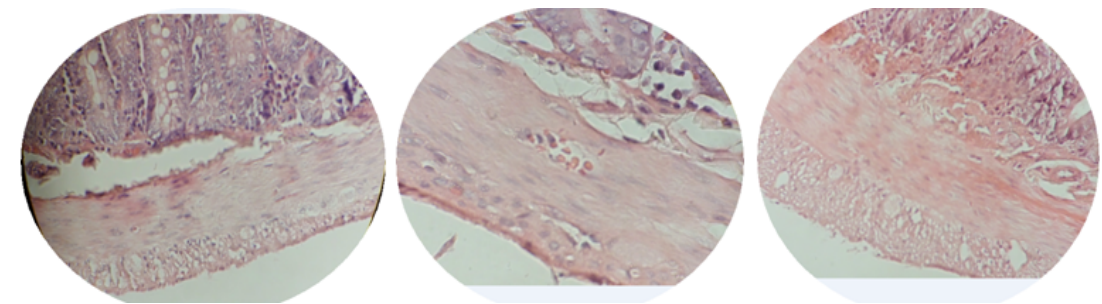

Figure 4. Photomicrographs of intestine using H\&E stain (100X). A) Control group B) $300 \mathrm{mg} / \mathrm{kg}$ group is showing no significant changes. C) $600 \mathrm{mg} / \mathrm{kg}$ group is showing increase of the thickness of mucous membrane and muscle thickness 
system improved [38]. The antimicrobial activity of propolis attributed to flavonoids and phenolic acids found in its composition $[39,40]$ because hydrophobicity of phenolic compounds disintegrates the outer membrane of gram- negative bacteria, and disturbing the bacterial structure [41] Flavonoids hinder the ability of pathogenic bacteria to adhere to the human intestinal epithelium [42]; thus increasing intestinal health and consequently increasing digestion and nutrient absorption [43].

Also Abozid and Ahmed in 2013 evaluated the effects of propolis on rat's liver function and demonstrated that there was no significant increase in body weight, related organs weight, fat level and liver functional parameters [44]. Using alcoholic extract of Propolis did not affected on serum potassium ions and alkaline phosphatase enzymes, but it may be poisoning at high doses [27]. In a study on ethanolic combination of propolis and vaccine against pasteurellosis in New Zealand rabbits indicated propolis has no side effects on general health and quality of the immune system [45].

In relation to the histological variables the findings of our study suggest that intestinal villi height, thickness of mucosal layer and Muscular significantly improved in the group $600 \mathrm{mg} / \mathrm{kg}$ with respect to the control group. While there was no significant difference in group $300 \mathrm{mg} / \mathrm{kg}$ compared to the control. Our results in group $600 \mathrm{mg} / \mathrm{kg}$ support the findings of [46] about the improving effects of plant extracts on digestive system villi morphology in poultry and pigs; the findings of [47] about the significantly improving effects of plant extracts on in testinal villi lengths and villi surface areas.

It is clear that increasing the thickness of the mucosal and muscular layers helps to digest food more effectively and rise the length of the villi could progress the amount of food absorption, which will indirectly improve the immune system efficiency.

\section{Conclusion}

It could be concluded from the present investigation that the propolis has positive effect on animal hygiene by increasing the immunity and decreasing the stress via increase the globulin level in the blood, but the beneficial effect of propolis seems to be dose dependent.

\section{References}

1. Myers SP, Cheras PA (2004) The other side of the coin: safety of complementary and alternative medicine. Medical Journal of Australia 181: 222-225.

2. Hyodo I, Amano N, Eguchi K, Narabayashi M, Imanishi J, et al (2005) Nationwide survey on complementary and alternative medicine in cancer patients in Japan. Journal of CLINICAL ONCOLOGY 23: 2645-2654.

3. Ahmad GH (1997) Propolis an overview. Prof, of Microbiology and Immunology, National Research Center.

4. Zhu W, Chen M, Shou Q, Li Y, Hu F (2011) Biological activities of Chinese propolis and Brazilian propolis on streptozotocin-induced type 1 diabetes mellitus in rats. EvidenceBased Complementary and Alternative Medicine.

5. Agarwal G, Vemanaradhya GG, Mehta DS (2012) Evaluation of chemical composition and efficacy of Chinese propolis extract on Porphyromonas gingivalis and Aggregatibacter actinomycetemcomitans: An in vitro study. Contemporary Clinical Dentistry 3: 256.

6. Fatoni A, Artika IM, Hasan AEZ (2008) Antibacterial activity of propolis produced by Trigona spp. against Campylobacter spp. HAYATI Journal of Biosciences 15: 161-164.

7. Marquez Hernandez I, Cuesta-Rubio O, Campo Fernandez M, Rosado Perez A, Montes de Oca Porto R, et al. (2010) Studies on the constituents of yellow Cuban propolis: GCMS determination of triterpenoids and flavonoids. Journal of Agricultural and Food Chemistry 58: 4725-4730.

8. Miguel MG, Nunes S, Dandlen SA, Cavaco AM, Antunes MD (2010) Phenols and antioxidant activity of hydro-alcoholic extracts of propolis from Algarve, South of Portugal. Food and Chemical Toxicology 48: 3418-3423.
9. Ahn MR, Kumazawa S, Hamasaka T, Bang KS, Nakayama T (2004) Antioxidant activity and constituents of propolis collected in various areas of Korea. Journal of Agricultural and Food Chemistry 52: 7286-7292.

10. Li Y, Chen M, Xuan H, Hu F (2012) Effects of encapsulated propolis on blood glycemic control, lipid metabolism, and insulin resistance in type 2 diabetes mellitus rats. Evidence-based Complementary and Alternative Medicine.

11. Hu F, Hepburn HR, Li Y, Chen M, Radloff SE, Daya S (2005) Effects of ethanol and water extracts of propolis (bee glue) on acute inflammatory animal models. Journal of Ethnopharmacology 100: 276-283.

12. de Castro Ishida VF, Negri G, Salatino A, Bandeira MFC (2011) A new type of Brazilian propolis: Prenylated benzophenones in propolis from Amazon and effects against cariogenic bacteria. Food Chemistry 125: 966-972.

13. Wang K, Ping S, Huang S, Hu L, Xuan H, et al. (2013) Molecular mechanisms underlying the in vitro anti-inflammatory effects of a flavonoid-rich ethanol extract from Chinese propolis (poplar type) Evidence-Based Complementary and Alternative Medicine.

14. Xuan H, Zhu R, Li Y, Hu F (2011) Inhibitory effect of chinese propolis on phosphatidylcholine-specific phospholipase $\mathrm{C}$ activity in vascular endothelial cells. Evidence-Based Complementary and Alternative Medicine.

15. Bankova VS, de Castro SL, Marcucci MC (2000) Propolis: recent advances in chemistry and plant origin. Apidologie 31: 3-15.

16. Ito J, Chang FR, Wang HK, Park YK, Ikegaki M, et al. (2001) Anti-AIDS agents. 48. Anti-HIV activity of moronic acid derivatives and the new melliferone-related triterpenoid isolated from Brazilian propolis. Journal of Natural Products 64: 12781281.

17. Pastor C, Sánchez-González L, Cháfer M, Chiralt A, González-Martínez C (2010) Physical and antifungal properties of hydroxypropylmethylcellulose based films containing propolis as affected by moisture content. Carbohydrate Polymers 82: 1174 1183.

18. Torlak E, Sert D (2013) Antibacterial effectiveness of chitosan-propolis coated polypropylene films against foodborne pathogens. International Journal of Biological Macromolecules 60: 52-55.

19. Siro B, Mady G (1998) Local treatment of rheumatic disease with propolis compound orvhetil.

20. El-Ghazaly MA, Khayyal MT (1995) The use of aqueous propolis extract against radiation-induced damage. Drugs Under Experimental and Clinical Research 21: 229236

21. Shehu A, Ismail S, Rohin MA K, Harun A, Aziz AA, Haque M (2016) Antifungal properties of Malaysian Tualang honey and stingless bee propolis against Candida albicans and Cryptococcus neoformans. Journal of Applied Pharmaceutical Science 6 : 044-050.

22. Rao PV, Krishnan KT, Salleh N, Gan SH (2016) Biological and therapeutic effects of honey produced by honey bees and stingless bees: a comparative review. Revista Brasileira de Farmacognosia 26: 657-664.

23. Hashimoto T, Tori M, Asakawa Y, Wollenweber E (1988) Synthesis of two allergenic constituents of propolis and poplar bud excretion. Zeitschrift für Naturforschung 43: $470-472$

24. Sompayrac LM (2011) How the immune system works. John Wiley \& Sons.

25. Pasupuleti M, Schmidtchen A, Malmsten M (2012) Antimicrobial peptides: key components of the innate immune system. Critical Reviews in Biotechnology 32: 143171

26. Farhadi A, Banan ALI, Fields J, Keshavarzian ALI (2003) Intestinal barrier: an interface between health and disease. Journal of Gastroenterology and Hepatology 18: 479-497.

27. Shittu OK, Lawal B, Alozieuwa BU, Haruna GM, Abubakar AN, et al. (2015) Alteration in biochemical indices following chronic administration of methanolic extract of Nigeria bee propolis in Wistar rats. Asian Pacific Journal of Tropical Disease 5: $654-657$.

28. Bashir L, Shittu OK, Busari MB, Sani S, Aisha MI (2015) Safety evaluation of gian African land snails (Archachatinamarginata) haemolymph on hematological and biochemical parameters of Albino rats. J Adv Med Pharm Sci 3: 122-130.

29. Sforcin JM, Novelli ELB, Funari SRC (2002) Seasonal effect of Brazilian propolis on seric biochemical variables. Journal of Venomous Animals and Toxins 8: 244-254.

30. Lauwerys RR, Bernard A, Roles H, Buchet JP (1995) Health risk assessment of longterm exposure to non-genotoxic chemicals: application of biological indices. Toxicology Letters 77: 39-44. 
31. Shahryar HA, Namvari M, Nourollahi H, Tili AS (2011) Effect of alcoholic extract propolis on immune system in broiler chickens. J Basic Appl Sci Res 1: 2094-2097.

32. Havsteen BH (2002) The biochemistry and medical significance of the flavonoids. Pharmacology and Therapeutics 96: 67-202.

33. Selem ASMA (2012) Effect of propolis on ruminal fermentation, reproductive and productive performance of Santa Inês ewes. Doctoral dissertation, Universidade de São Paulo.,

34. Barwary MS, Mshabaz RA (2016) The effect of propolis administration on hematological and biochemical parameters of Karadi ewes. In The 2nd Scientific Agricultural Conference, pp: 88.

35. Kashkooli OB, Dorcheh EE, Mahboobi-Soofiani N, Samie A (2011) Long-term effects of propolis on serum biochemical parameters of rainbow trout (Oncorhynchus mykiss). Ecotoxicology and Environmental Safety 74: 315-318.

36. Ghisalberti EL (1979) Propolis: A review. Bee World 60: 59-84

37. Kong X, Hu Y, Rui R, Wang D, Li X (2004) Effects of Chinese herbal medicinal ingredients on peripheral lymphocyte proliferation and serum antibody titer after vaccination in chicken. International Immunopharmacology 4: 975-982.

38. Abdel-Mohsein HS, Mahmoud MA, Mahmoud UT (2014) Influence of propolis on intestinal microflora of Ross broilers exposed to hot environment. Adv Anim Vet Sci 2014: 3-23.

39. Mukherjee PK, Maiti K, Mukherjee K, Houghton PJ (2006) Leads from Indian medicinal plants with hypoglycemic potentials. Journal of Ethnopharmacology 106 $1-28$.
40. Jasprica I, Mornar A, Debeljak Ž, Smolčić-Bubalo A, Medić-Šarić M, et al. (2007) In vivo study of propolis supplementation effects on antioxidative status and red blood cells. Journal of Ethnopharmacology 110: 548-554.

41. Liu XL, Xu YJ, Go ML (2008) Functionalized chalcones with basic functionalities have antibacterial activity against drug sensitive Staphylococcus aureus. European Journal of Medicinal Chemistry 43: 1681-1687.

42. Parkar SG, Stevenson DE, Skinner MA (2008) The potential influence of fruit polyphenols on colonic microflora and human gut health. International Journal of Food Microbiology 124: 295-298.

43. Denli M, Cankaya S, Silici S, Okan F, Uluocak AN (2005) Effect of dietary addition of Turkish propolis on the growth performance, carcass characteristics and serum variables of quail (Coturnix coturnix japonica) Asian-Australasian Journal of Animal Sciences 18: 848-854.

44. Abozid MM, Ahmed AA (2013) Chemical composition of Egyptian and commercia propolis and its effects on liver function and lipid profiles in albino rats. $J$ Biol Chem Env Res 8: 323-340.

45. Nassar SA, Mohamed AH, Soufy H, Nasr SM, Mahran KM (2012) Immunostimulant effect of Egyptian propolis in rabbits. The Scientific World Journal.

46. Bruggeman G, Deschepper K, Molly K (2002) Plant antibacterials suit modern production. Feed Mix 10: 18-19.

47. Catala P, Garcia V, Orengo J, Madrid J, Hernández F, et al. (2004) Effect of plant extracts and chickens' location on intestine mucosal morphology and ileal apparen digestibility of broilers. In: XXII World's Poultry Congress Book of Abstracts, İstanbul, Turkey, pp: 456

Copyright: (C2019 Bayrami M. This is an open-access article distributed under the terms of the Creative Commons Attribution License, which permits unrestricted use, distribution, and reproduction in any medium, provided the original author and source are credited. 